\title{
Systematic evaluation of the degraded products evolved from the hydrothermal pretreatment of sweet sorghum stems
}

\author{
Shaolong Sun, Jialong Wen, Shaoni Sun and Run-Cang Sun ${ }^{*}$
}

\begin{abstract}
Background: Conversion of plant cell walls to bioethanol and bio-based chemicals requires pretreatment as a necessary step to reduce recalcitrance of cell walls to enzymatic and microbial deconstruction. In this study, the sweet sorghum stems were subjected to various hydrothermal pretreatment processes $\left(110^{\circ} \mathrm{C}\right.$ to $230^{\circ} \mathrm{C}, 0.5$ to $2.0 \mathrm{~h}$ ), and the focus of this work is to systematically evaluate the degraded products of polysaccharides and lignins in the liquor phase obtained during the pretreatment process.
\end{abstract}

Results: The maximum yield of xylooligosaccharides (52.25\%) with a relatively low level of xylose and other degraded products was achieved at a relatively high pretreatment temperature $\left(170^{\circ} \mathrm{C}\right)$ for a short reaction time $(0.5 \mathrm{~h})$. Higher temperature $\left(>170^{\circ} \mathrm{C}\right)$ and/or longer reaction time $\left(>0.5 \mathrm{~h}\right.$ at $\left.170^{\circ} \mathrm{C}\right)$ resulted in a decreasing yield of xylooligosaccharides, but increased the concentration of arabinose and galactose. The xylooligosaccharides obtained are composed of xylopyranosyl residues, together with lower amounts of 4-O-Me-a-D-GlcpA units. Meanwhile, the concentrations of the degraded products (especially furfural) increased as a function of pretreatment temperature and time. Molecular weights of the water-soluble polysaccharides and lignins indicated that the degradation of the polysaccharides and lignins occurred during the conditions of harsh hydrothermal pretreatment. In addition, the water-soluble polysaccharides (rich in xylan) and water-soluble lignins (rich in $\beta$-O-4 linkages) were obtained at $170^{\circ} \mathrm{C}$ for $1.0 \mathrm{~h}$.

Conclusions: The present study demonstrated that the hydrothermal pretreatment condition had a remarkable impact on the compositions and the chemical structures of the degraded products. An extensive understanding of the degraded products from polysaccharides and lignins during the hydrothermal pretreatment will be beneficial to value-added applications of multiple chemicals in the biorefinery for bioethanol industry.

Keywords: Sweet sorghum stem, Hydrothermal pretreatment, Degraded products, Heteronuclear single quantum coherence (HSQC)

\section{Background}

Lignocelluloses have huge growth potential due to their contribution to the bioethanol production and to decrease $\mathrm{CO}_{2}$ emission and global warming in recent years $[1,2]$. Sweet sorghum is considered as one of the potential renewable sources of energy for economic development and environmental sustainability, owing to its wide adaptability and high concentration of soluble sugars [3]. This plant could be effectively used as a source

\footnotetext{
* Correspondence: rcsun3@bjfu.edu.cn

No. 35 Tsing Hua East Road, Haidian District, Beijing Key Laboratory of Lignocellulosic Chemistry, Beijing Forestry University, Beijing 100083, China
}

of fodder (stem), food (grains), and also as feedstock (cellulose, hemicelluloses, and lignins) for the production of industrial chemicals $[3,4]$. However, in the production of bioethanol, the direct enzymatic hydrolysis of cellulose is greatly hampered by the dense and complex architectural structure of biomass [5]. Since pretreatment accelerates enzymes accessing the rigid structure of biomass for maximum yield of fermentable sugar, pretreatment is considered as a crucial link prior to biomass enzymatic hydrolysis $[5,6]$. By now, a variety of physical, chemical, mechanical, and biological pretreatment techniques have been developed, including the developments of steam explosion, organosolv pretreatment, and hydrothermal 
pretreatment (HTP) [7-9]. Among them, HTP is a handy and eco-friendly technology for the pretreatment of lignocelluloses as compared to others, since the medium only contains water, avoiding corrosion of equipment [10]. In addition, HTP can result in structural changes of lignins and cellulose as well as solubilization of hemicelluloses, which in turn contribute to the improved enzyme accessibility in pretreated biomass [10]. Furthermore, HTP can also produce some important by-products, such as xylo-oligosaccharides (XOS), and some other chemicals (for example, furfural, formic acid, and acetic acid) [11]. The fundamental understanding of the degraded products can increase high-value utilization of biomass in a biorefinery process [12]. Therefore, it is necessary to characterize the degraded products in the liquors recovered during the HTP, which will enhance biorefinery viability in the future.

In this study, the sweet sorghum stems (SSS) were subjected to different HTP conditions $\left(110^{\circ} \mathrm{C}\right.$ to $230^{\circ} \mathrm{C}$, 0.5 to $2.0 \mathrm{~h}$ ). For the substrates obtained after the HTP process, the enzymatic hydrolysis efficiency and structural properties have been thoroughly investigated in a recent publication [13]. This work mainly focuses on chemical characteristics of the degraded products in the liquor phase produced during the HTP process. Among them, the XOS, monosaccharides, and degree of polymerization of XOS were analyzed by high-performance anion exchange chromatography (HPAEC). Structural features of the XOS were identified by two-dimensional heteronuclear single quantum coherence (2D-HSQC). The chemical features (composition, molecular weights, and structural features) of the water-soluble polysaccharides and lignins (WSPs and WSLs) obtained from the liquor phase during the HTP process were systematically evaluated by HPAEC, gel permeation chromatography (GPC), and 2D-HSQC NMR, which will contribute to the potential applications in bioethanol industry under the biorefinery scenario. The schematic diagram of the experimental procedure is illustrated in Figure 1.

\section{Results and discussion}

The liquor $\mathrm{pH}$

The $\mathrm{pH}$ of the initial liquor before heating was 6.80, and it decreased to 3.13 with the increasing HTP temperature and time (Table 1). This is expected that the hydronium ions released by the water during the HTP cause depolymerization of hemicelluloses by selective hydrolysis

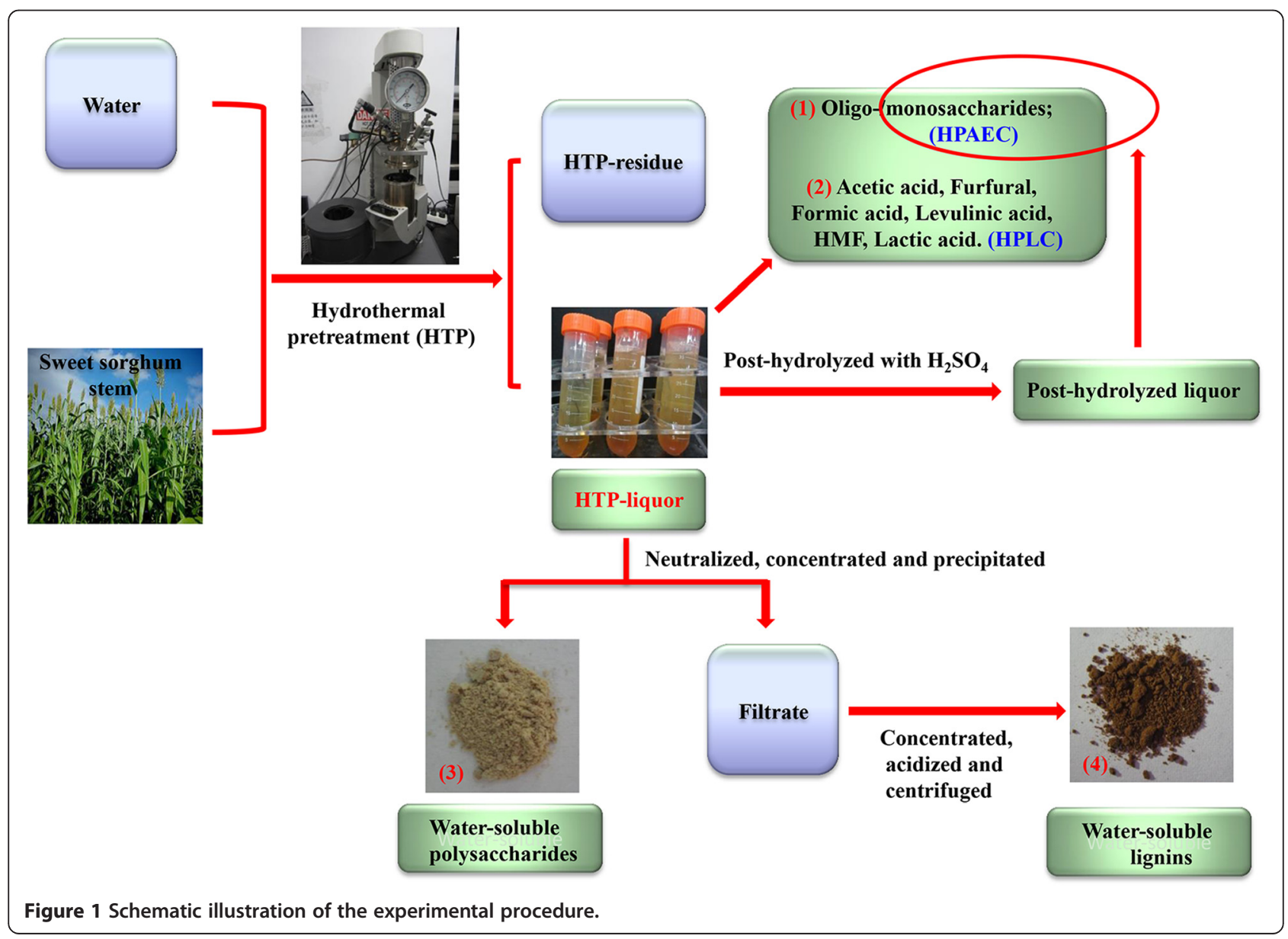


Table 1 The liquor $\mathrm{pH}$ and the degraded products of polysaccharides from sweet sorghum stem during the hydrothermal pretreatment process

\begin{tabular}{lllllllll}
\hline $\begin{array}{l}\text { Temperature } \\
\left({ }^{\circ} \mathbf{C}\right)-\text { time (h) }\end{array}$ & \begin{tabular}{l} 
Degraded products (g/L) \\
\cline { 2 - 7 }
\end{tabular} & $\begin{array}{l}\text { Formic } \\
\text { acid }\end{array}$ & $\begin{array}{l}\text { Acetic } \\
\text { acid }\end{array}$ & $\begin{array}{l}\text { Levulinic } \\
\text { acid }\end{array}$ & $\begin{array}{l}\text { Lactic } \\
\text { acid }\end{array}$ & HMF & Furfural & \\
\hline $110-1.0$ & ND & ND & ND & ND & ND & ND & 5.18 \\
$130-1.0$ & ND & ND & ND & ND & ND & ND & 4.50 \\
$150-1.0$ & 1.10 & 0.38 & 0.52 & ND & 0.06 & ND & 3.78 \\
$170-0.5$ & 0.85 & 0.48 & 0.74 & 0.28 & 0.12 & 0.18 & 3.65 \\
$170-1.0$ & 1.96 & 0.63 & 1.39 & 0.37 & 0.21 & 0.85 & 3.48 \\
$170-2.0$ & 2.26 & 1.01 & 2.26 & 0.73 & 0.32 & 2.11 & 3.30 \\
$190-0.5$ & 2.56 & 1.26 & 2.43 & 1.65 & 0.38 & 3.32 & 3.22 \\
$210-0.5$ & 3.16 & 1.64 & 2.95 & 2.20 & 1.23 & 3.50 & 3.18 \\
$230-0.5$ & 3.76 & 4.03 & 3.65 & 2.41 & 2.27 & 4.53 & 3.13 \\
\hline
\end{tabular}

ND, not detectable. Data represented are the averages of the results obtained from the duplicated experiments.

of glycosidic linkages, liberating $\mathrm{O}$-acetyl group and other acid moieties to form various acids (such as acetic and uronic acids). The release of these acids is thought to catalyze the hydrolysis of hemicelluloses and oligosaccharides, resulting in more hemicelluloses that were degraded and solubilized in the liquor as the pretreatment temperature and time increased [14]. This is also the main reason for decreasing solid yields from $92.4 \%$ to $51.5 \%$ as the pretreatment temperature and time increased. Similarly, the strong positive correlations between the $\mathrm{pH}$ of the liquor and the solid yield have been also observed in a previous study [15].

\section{Xylo-oligosaccharides and monosaccharides}

Hemicelluloses (xylan-type) in lignocelluloses are hydrolyzed to xylose or xylo-oligomers during the HTP $[6,16,17]$. In general, the degree of xylan hydrolysis increases as the HTP severity increases [14]. In this study, the hydrolysis products in the liquor were mainly XOS and monosaccharides. Figure 2 shows the yields of XOS and monosaccharides as the pretreatment temperature and time increased during the HTP. As can be seen (Figure 2A), the yields of XOS (based on the initial xylan in raw material) steadily increased from $3.18 \%$ to $47.20 \%$ with an increase in the pretreatment temperature from $110^{\circ} \mathrm{C}$ to $170^{\circ} \mathrm{C}$ for a constant time $(1.0 \mathrm{~h})$. The reason for this is that more xylan was degraded and solubilized in the liquor at the elevated temperatures. Specially, the maximum yield of XOS $(52.25 \%)$ was achieved in a relatively short period $(0.5 \mathrm{~h})$ at $170^{\circ} \mathrm{C}$. When the pretreatment time was further prolonged to 1.0 and $2.0 \mathrm{~h}$ at $170^{\circ} \mathrm{C}$, the yield of XOS decreased constantly with the prolongation of reaction time. The fact suggested that the prolongation of reaction time was adverse to the production of XOS at $170^{\circ} \mathrm{C}$ for $0.5 \mathrm{~h}$. As expected, when the pretreatment temperature was higher than $170^{\circ} \mathrm{C}$ at a constant short time $(0.5 \mathrm{~h})$, the yields of XOS constantly decreased from $52.25 \%$ to $0.37 \%$ (in the experiment performed at $230^{\circ} \mathrm{C}$ ). This was attributed to the fact that almost all the xylan was degraded into the xylose and other small molecules, resulting in only a small amount of XOS detected in the liquor phase under this condition [18]. Taken together, the optimal yield of XOS was achieved in the case of the material pretreated at $170^{\circ} \mathrm{C}$ for $0.5 \mathrm{~h}$. Hence, this condition was considered as a promising pathway to obtain high-yield of XOS from SSS by the HTP process.

Figure 2A also illustrates that the yield of xylose (based on the initial xylan in raw material) was obtained at various pretreatment conditions. When the pretreatment time was $1.0 \mathrm{~h}$, a significant enhancement of xylose concentration was observed as the pretreatment temperature increased from $110^{\circ} \mathrm{C}$ to $170^{\circ} \mathrm{C}$, and a higher pretreatment temperature and longer pretreating period resulted in a rapid raise of xylose. The maximum yield of xylose was achieved $\left(21.47 \%\right.$ of the initial xylan) at $170^{\circ} \mathrm{C}$ for $2.0 \mathrm{~h}$. The concentration variations of arabinose and galactose at various pretreatment conditions are shown in Figure 2B. The change of galactose concentration was quite similar to that of xylose, whose maximum concentration was also obtained $(0.44 \mathrm{~g} / \mathrm{L})$ at $170^{\circ} \mathrm{C}$ for $2.0 \mathrm{~h}$. The highest arabinose concentration was observed $(2.36 \mathrm{~g} / \mathrm{L})$ at $170^{\circ} \mathrm{C}$ for $0.5 \mathrm{~h}$. Under the optimal pretreatment condition for $\mathrm{XOS}\left(170^{\circ} \mathrm{C}\right.$ for $\left.0.5 \mathrm{~h}\right)$, the concentrations of arabinose and galactose were 2.36 and $0.21 \mathrm{~g} / \mathrm{L}$, respectively. Moreover, low concentrations of glucose were detected in the liquors pretreated at harsh conditions (that is, $0.59 \mathrm{~g} / \mathrm{L}$ at $210^{\circ} \mathrm{C}$ for $0.5 \mathrm{~h}$ and $0.48 \mathrm{~g} / \mathrm{L}$ at $230^{\circ} \mathrm{C}$ for $0.5 \mathrm{~h}$, respectively), indicating that the part of non-crystalline cellulose may be hydrolyzed under the conditions given.

\section{Degree of polymerization and HSQC analysis of xylo-oligosaccharides}

A systematic study was proposed for the production, purification, and applications of XOS as food additives and nutraceuticals. Considered as food ingredients, XOS have favorable modulation on the intestinal function [19]. In the present study, the degree of polymerization (DP) of XOS obtained during the HTP from SSS was determined. Figure 3 presents the concentration and DP distribution of XOS. The concentrations of xylobiose, xylotriose, xylotetraose, xylopentaose, and xylohexaose were determined by HPAEC. The total concentration of XOS was determined by an increasing concentration of monosaccharides after post-hydrolysis.

The DP of XOS illustrated that it was influenced by the pretreatment temperature and time. As the pretreatment temperature increased $\left(110^{\circ} \mathrm{C}\right.$ to $\left.170^{\circ} \mathrm{C}, 1.0 \mathrm{~h}\right)$, more low-DP XOS (DP 2 to 6) were obtained. However, when the pretreatment temperature further increased from $170^{\circ} \mathrm{C}$ 

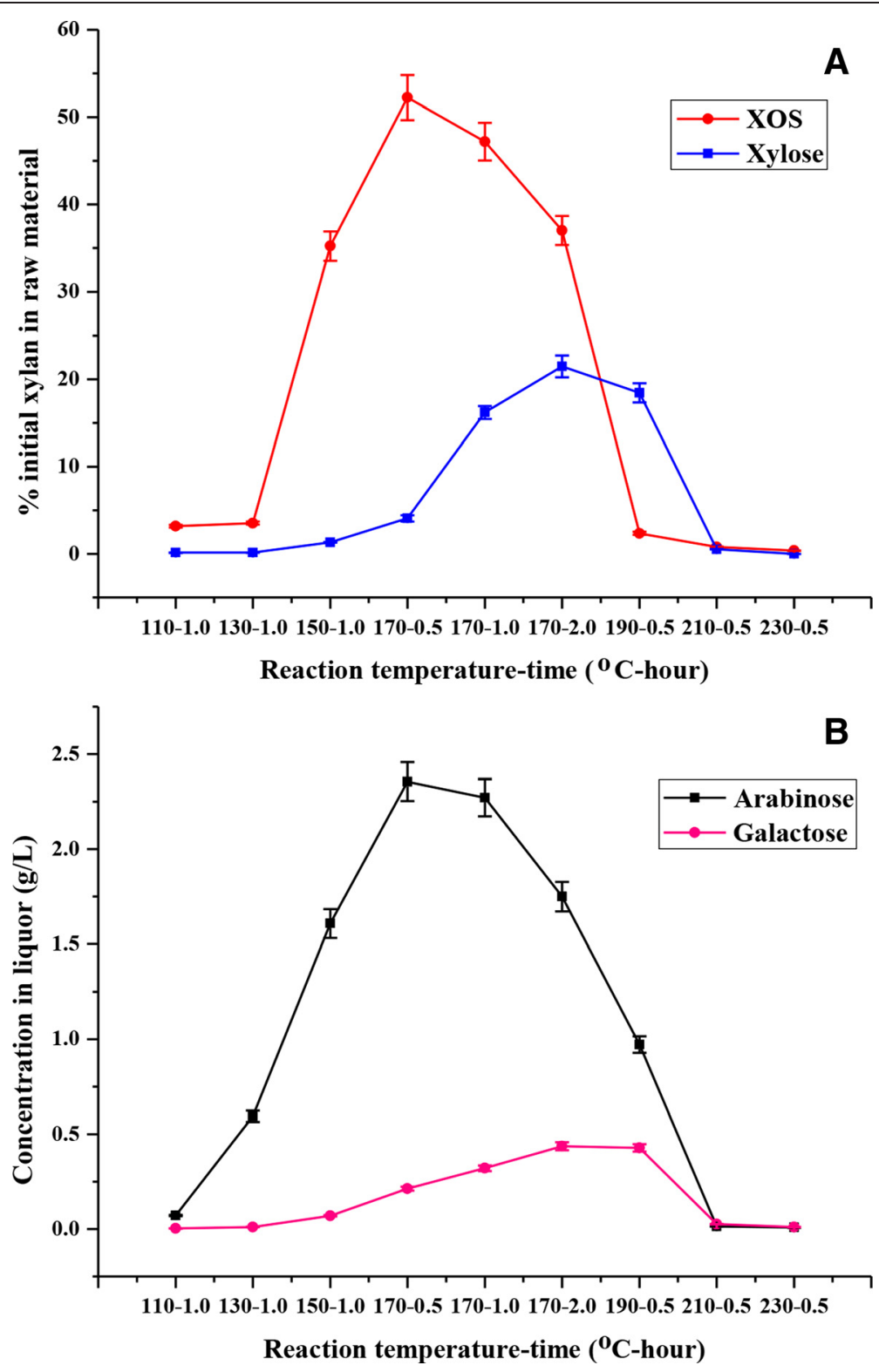

Figure 2 Experimental values for (A) XOS and xylose, (B) arabinose, and galactose obtained during the hydrothermal pretreatment at $110^{\circ} \mathrm{C}$ to $230^{\circ} \mathrm{C}$. The yields of XOS and xylose are expressed as the percentage of the xylan in raw materials. The concentrations of arabinose and galactose are expressed as the concentration in the liquor phase. The error bars are standard deviations from experiments performed in duplicate. XOS, xylo-oligosaccharides.

to $230^{\circ} \mathrm{C}$, the yields of low-DP XOS (DP 2 to 6) rapidly declined with the pretreatment severity. The maximum yield of XOS was achieved with $14.05 \%$ xylobiose $(2.12 \mathrm{~g} / \mathrm{L})$, 9.61\% xylotriose $(1.45 \mathrm{~g} / \mathrm{L}), 4.71 \%$ xylotetraose $(0.71 \mathrm{~g} / \mathrm{L})$, $16.10 \%$ xylopentaose $(2.43 \mathrm{~g} / \mathrm{L}), \quad 5.04 \%$ xylohexaose $(0.76 \mathrm{~g} / \mathrm{L})$, and $50.49 \%$ high-DP XOS $(\mathrm{DP}>6)(7.63 \mathrm{~g} / \mathrm{L})$ at $170^{\circ} \mathrm{C}$ for $0.5 \mathrm{~h}$. However, when the reaction time was prolonged to $1.0 \mathrm{~h}$ at $170^{\circ} \mathrm{C}$, the yield of low-DP XOS (DP 2 to 6$)$ increased but the high-DP XOS (DP $>6)$ decreased. After further prolonging the reaction time to $2.0 \mathrm{~h}$, the low and high-DP XOS simultaneously reduced. These phenomena were probably due to the XOS that was further degraded into other small molecules (such as furfural) under the harsh conditions, as revealed by the subsequent degraded products analysis in the liquors produced during the HTP from SSS.

A 2D-HSQC spectrum (Figure 4) was used to identify the various structural features of XOS obtained under the pretreated at $170^{\circ} \mathrm{C}$ for $0.5 \mathrm{~h}$. The signals of the XOS were interpreted as follows: (a) reducing end xylopyranosyl (Xylp) residues of $\alpha$ and $\beta$ conformations $\left(\delta_{\mathrm{C}} / \delta_{\mathrm{H}} 92.0 / 5.13\right.$ and 96.5/4.52); (b) internal Xylp residues $(1 \rightarrow 4)$ - $\beta$-D-Xylp, 


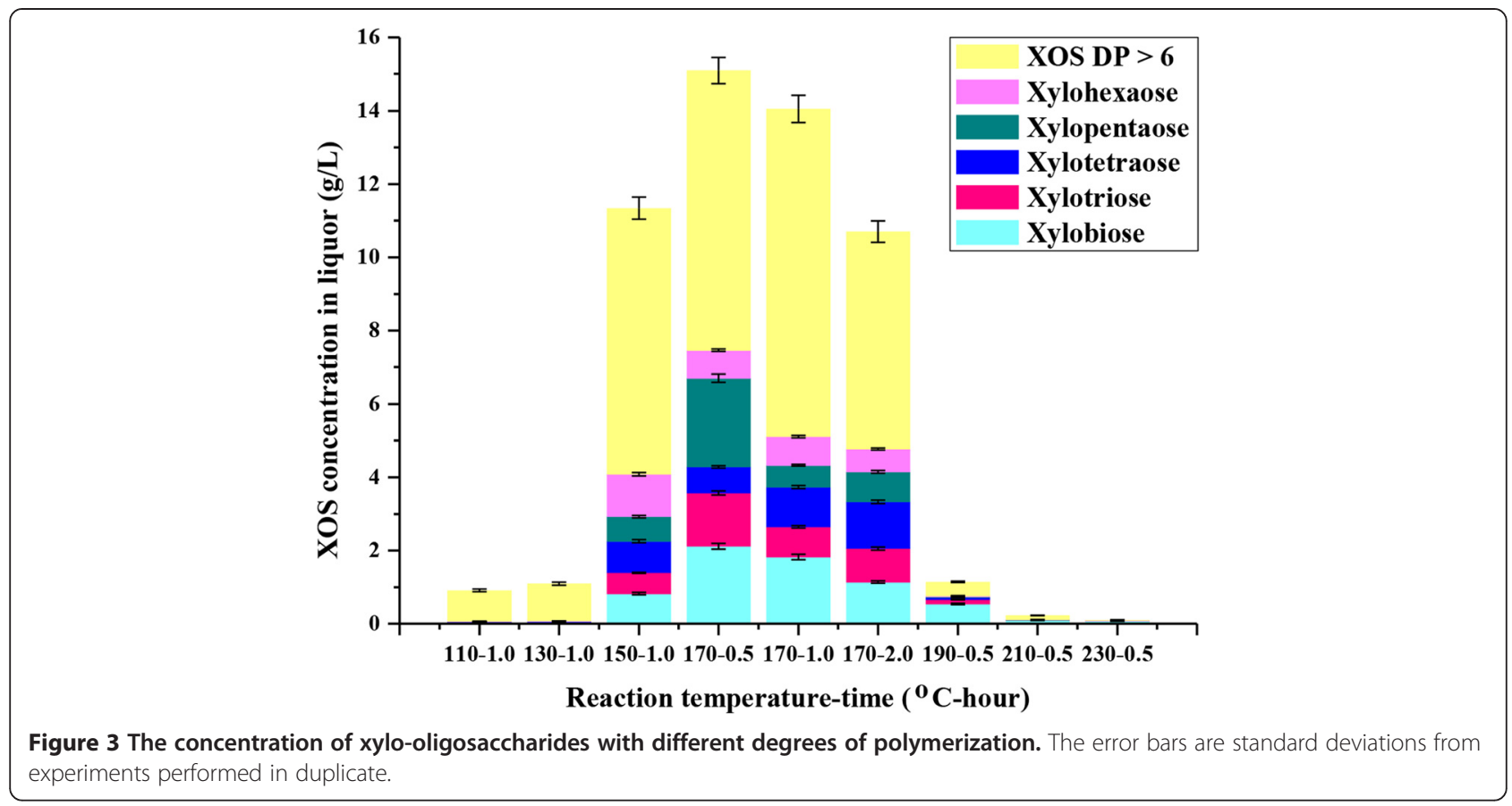

that is, $\delta_{\mathrm{C}} / \delta_{\mathrm{H}} 101.6 / 4.40\left(\mathrm{C}_{1}-\mathrm{H}_{1}\right), 72.6 / 3.23\left(\mathrm{C}_{2}-\mathrm{H}_{2}\right)$, 73.6/3.49 $\left(\mathrm{C}_{3}-\mathrm{H}_{3}\right), 76.3 / 3.72\left(\mathrm{C}_{4}-\mathrm{H}_{4}\right), 62.9 / 4.04\left(\mathrm{C}_{5 \mathrm{eq}}-\mathrm{H}_{5 \mathrm{eq}}\right)$, and 62.9/3.32 $\left(\mathrm{C}_{5 \mathrm{ax}}-\mathrm{H}_{5 \mathrm{ax}}\right)$; (c) terminal (non-reducing end) Xylp residues $\left(\beta-\mathrm{D}-\mathrm{Xylp}-\left(1-\right.\right.$, that is, $\delta_{\mathrm{C}} / \delta_{\mathrm{H}} 75.6 / 3.37$ and 69.2/3.56); and (d) a small amount of Xylp units attached with 4-O-Me- $\alpha$-D-GlcpA units $\left(\delta_{\mathrm{C}} / \delta_{\mathrm{H}} \quad 72.6 / 3.60\right.$ and $59.9 / 3.40)$. Many groups exhibited unequal intensities, indicating that the XOS contained a mixture of several molecules. The XOS showed a low degree of branching according to the weak signals of 4-O-Me- $\alpha$-D-GlcpA residues. Note that the structural features of XOS are dependent not only on the origin of the xylan-rich hemicelluloses but also on the process [20]. For example, XOS prepared from xylan-rich hemicelluloses, isolated using aqueous potassium hydroxide from delignified sugarcane bagasse, by hydrolysis with crude xylanase secreted by Pichia stipitis contained Araf and 4-O-Me- $\alpha$-D-GlcpA residues [21].

\section{Degraded products of polysaccharides}

The main degraded products of polysaccharides from lignocelluloses during the HTP were acetic acid, furfural, hydroxymethylfurfural (HMF), and formic acid, which were described in detail in a recent publication [18]. As can be seen, hemicelluloses are partially acetylated and the acetyl ester bonds are hydrolyzed to produce acetic acid under the HTP process. Furfural is a pentose dehydration product and can be further degraded through hydrolytic fission of the aldehyde group to formic acid under the acidic hydrothermal condition [22]. HMF is a dehydration product of hexose sugars (glucose, galactose, and mannose) and can be further transformed into levulinic and formic acids under the acidic condition [23]. These degraded products are undesirable, since they act as inhibitors of the fermentation process [24].

In this study, acetic acid, furfural, HMF, formic acid, levulinic acid, and lactic acid were found to be the main degraded products detected in the liquor fractions. The concentrations of the degraded products of polysaccharides in the liquor phase were listed in Table 1 . The concentrations of acetic acid ( $4.03 \mathrm{~g} / \mathrm{L})$ and furfural $(4.53 \mathrm{~g} / \mathrm{L})$ were significantly higher than other degraded products $(<3.76 \mathrm{~g} / \mathrm{L})$ at the severest pretreatment condition. It was interesting to note that the release of all degraded products was closely related to the pretreatment temperature and time, that is, the concentrations of all degraded products increased with increasing temperature at a constant time or increasing time at a constant temperature. As expected, the maximum concentrations of all degraded products were observed in the case of the material pretreated at $230^{\circ} \mathrm{C}$ for $0.5 \mathrm{~h}$, corresponding to the severest experimental condition in this work. It appears that the HTP condition under the higher HTP temperature at a short reaction time (that is, $230^{\circ} \mathrm{C}$ for $0.5 \mathrm{~h}$ ) favors the dehydration of xylose to furfural as compared to that obtained at other experiment conditions. The concentration of HMF remained low throughout among the whole range of pretreatment severities due to limited cellulose solubilization and consequent glucose formation. The concentration of levulinic acid was much lower than that of formic acid, suggesting that most of formic acid was produced from furfural and 


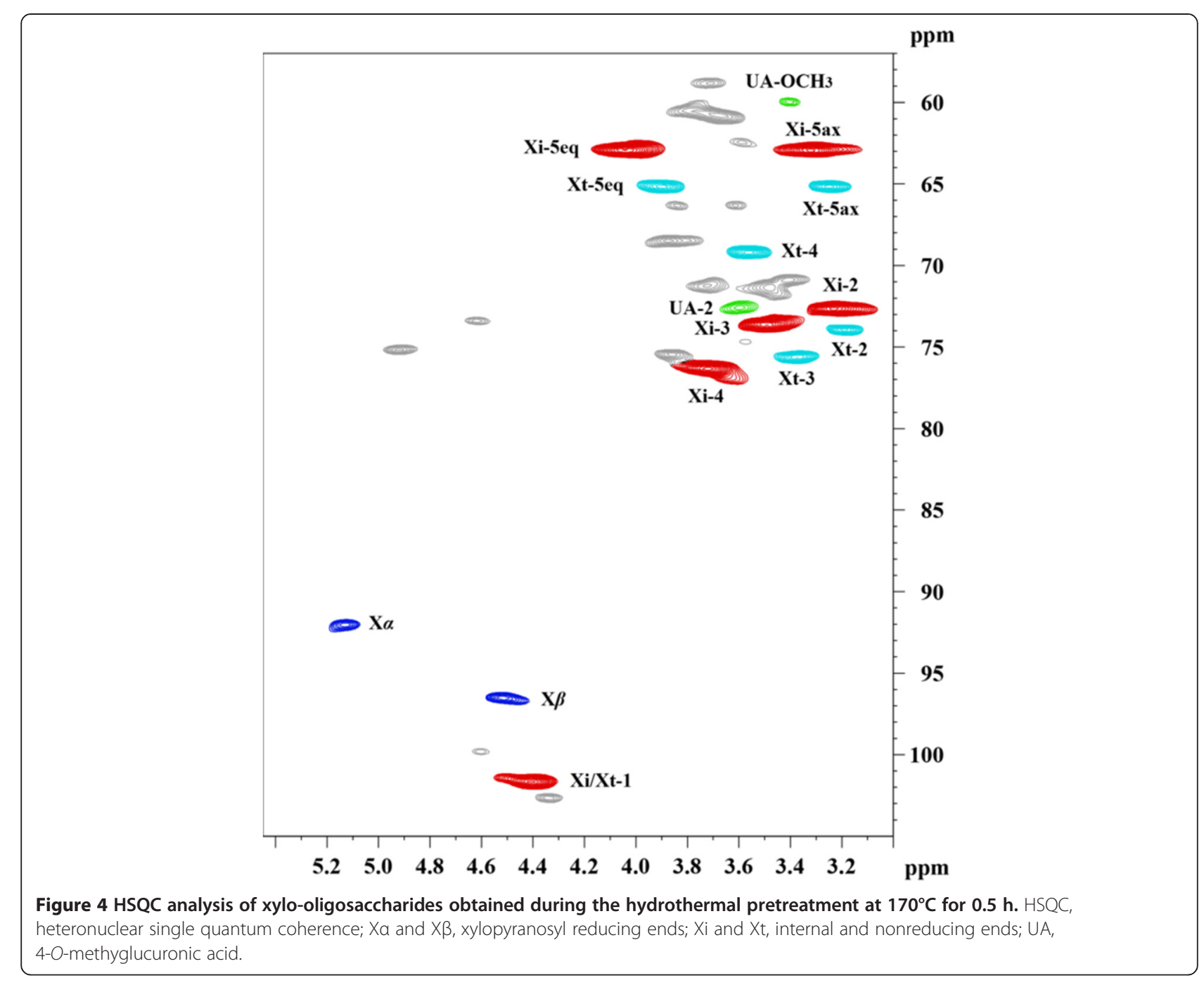

not from HMF degradation, since the latter would lead to the production of equimolar amounts of levulinic and formic acids [18].

\section{Water-soluble polysaccharides}

The composition of the WSPs obtained from the HTP-liquor phase is presented in Table 2. These WSPs contained most xylose and glucose together with small amount of arabinose, galactose, rhamnose, mannose, and uronic acids (glucuronic and galacturonic acids). Under the HTP temperature lower than $210^{\circ} \mathrm{C}$, the content of xylose was apparently higher than glucose in the WSPs. In contrast, as the HTP temperature over $190^{\circ} \mathrm{C}$, the content of glucose predominates over xylose in the WSPs. The high content of glucose in the two WSPs $\left(\mathrm{WSP}_{210(0.5)}\right.$ and $\left.\mathrm{WSP}_{230(0.5)}\right)$ was probably related to the hydrolysis of amorphous cellulose under the harsh conditions. The amorphous cellulose may be hydrolyzed to the cellulosic fragment, resulting in part of cellulose that was co-precipitated in the WSPs. Table 3 exhibits weight average $\left(M_{w}\right)$ and number average $\left(M_{n}\right)$ molecular weights along with polydispersity indexes (PDIs, $M_{w} / M_{n}$ ) of the WSPs. The $M_{w}$ and $M_{n}$ of the WSPs gradually reduced as the pretreatment temperature and time increased, implying that the C-O bonds of the WSP was gradually cleaved, especially at the harsh conditions $\left(\geq 170^{\circ} \mathrm{C}\right)$. In addition, these WSPs with lower PDIs $(1.10$ to 2.01) suggested that the HTP process yielded more homogeneous polysaccharide polymers.

Structural features of the WSPs WSP $_{130(1.0)}$ and WSP $_{170(1.0)}$ ) were determined by 2D-HSQC NMR technique (Figure 5). Comparison of HSQC spectra of the WSPs obtained from the liquor phase can help to better understand the structural variation of the WSPs during the HTP process. For $\mathrm{WSP}_{130(1.0)}$, cross signals of $(1 \rightarrow 4)$-linked $\beta$-D-Xyl $p$ units at $\delta_{\mathrm{C}} / \delta_{\mathrm{H}}$ 102.0/4.31 $\left(\mathrm{C}_{1}-\mathrm{H}_{1}\right), 73.2 / 3.15\left(\mathrm{C}_{2}-\mathrm{H}_{2}\right), 74.5 / 3.38\left(\mathrm{C}_{3}-\mathrm{H}_{3}\right)$, 76.0/3.63 $\left(\mathrm{C}_{4}-\mathrm{H}_{4}\right), 62.9 / 3.94\left(\mathrm{C}_{5 \mathrm{eq}}-\mathrm{H}_{5 \mathrm{eq}}\right)$, and $63.3 / 3.25$ $\left(\mathrm{C}_{5 \mathrm{ax}}-\mathrm{H}_{5 \mathrm{ax}}\right)$ were clearly observed. The signals of $\alpha$-Larabinofuranosyl units were found at $\delta_{\mathrm{C}} / \delta_{\mathrm{H}} 109.4 / 5.15$, 
Table 2 Relative content of sugars and uronic acids of the water-soluble polysaccharides isolated from the hydrothermally pretreated liquor phase under the various processing conditions

\begin{tabular}{llllllll}
\hline $\begin{array}{l}\text { Temperature } \\
\left({ }^{\circ} \mathbf{C}\right) \text {-time }(\mathbf{h})\end{array}$ & \multicolumn{2}{l}{ Neutral sugars and uronic acids } & & & & \\
\cline { 2 - 6 } & Rhamnose & Arabinose & Galactose & Glucose & Xylose & Mannose & Uronic acid \\
\hline $110-1.0$ & 1.76 & 21.34 & 10.13 & 27.48 & 33.69 & 0.94 & 4.66 \\
$130-1.0$ & 0.95 & 21.02 & 10.24 & 26.63 & 37.86 & 0.29 & 3.01 \\
$150-1.0$ & ND & 6.27 & 6.07 & 21.04 & 65.56 & ND & 1.06 \\
$170-0.5$ & ND & 3.42 & 4.17 & 14.59 & 77.28 & ND & 0.54 \\
$170-1.0$ & ND & 6.72 & 5.49 & 21.02 & 66.77 & ND & ND \\
$170-2.0$ & ND & 6.50 & 4.17 & 20.23 & 69.10 & ND & ND \\
$190-0.5$ & ND & 5.76 & 3.02 & 18.64 & 72.58 & ND & ND \\
$210-0.5$ & ND & ND & 2.63 & 81.16 & 16.21 & ND & ND \\
$230-0.5$ & ND & ND & ND & 82.68 & 17.32 & ND & ND \\
\hline
\end{tabular}

$\mathrm{ND}$, not detectable. Data represented are the averages of the results obtained from the duplicated experiments.

80.1/3.93, 78.3/3.67, 86.3/4.09, and 61.2/3.65, which are characteristic of $\mathrm{C}_{1}-\mathrm{H}_{1}, \mathrm{C}_{2}-\mathrm{H}_{2}, \mathrm{C}_{3}-\mathrm{H}_{3}, \mathrm{C}_{4}-\mathrm{H}_{4}$, and $\mathrm{C}_{5}-\mathrm{H}_{5}$, respectively. Some weak signals at $\delta_{\mathrm{C}} / \delta_{\mathrm{H}} 97.4 / 5.16,71.5 /$ 3.42, 74.0/3.73, 82.4/3.08, 72.1/4.19, and 59.6/3.33 are assigned to $\mathrm{C}_{1}-\mathrm{H}_{1}, \mathrm{C}_{2}-\mathrm{H}_{2}, \mathrm{C}_{3}-\mathrm{H}_{3}, \mathrm{C}_{4}-\mathrm{H}_{4}, \mathrm{C}_{5}-\mathrm{H}_{5}$, and $-\mathrm{OCH}_{3}$ of 4-O-Me- $\alpha$-D-GlcpA units, respectively [25,26]. As the HTP temperature was further increased to $170^{\circ} \mathrm{C}$ and kept for $1.0 \mathrm{~h}$, only the cross signals of $\beta$-D-Xyl $p$ units were observed, implying that the xylan-rich polymers (WSP $_{170(1.0)}$ ) were collected. This is because that the side chains of the WSP macromolecules were significantly cleaved under this condition. These results suggested that the degradation degree of xylans increased with the HTP temperature increase, as revealed by the aforementioned molecular weight analysis.

\section{Water-soluble lignins}

Lignin is considered the most persistent component of the plant cell wall biopolymers [27]. It is found primarily in the secondary cell wall and plays a major role in pathogen resistance, water regulation, and conferring strength for the integrity of the cell wall structure. The effects of lignin on biomass enzymatic digestibility have received extensive attention $[10,28]$. It is generally recognized that the existence of lignins in lignocelluloses restricts enzymatic saccharification by physically impeding the accessibility of cellulase to cellulose [10]. HTP causes fragmentation of lignins, which results in the redistribution of lignins and its structural changes depending on the HTP severity [29]. It has been reported that a decrease in molecular weight of native lignins would facilitate its dissolution and/or migration to the surface in the reaction media during the HTP [10]. The spherical droplets found in the pretreated hardwood are thought to be mainly composed of lignins based on previous reports [30,31]. In addition, pseudo-lignin derived from the dehydrated carbohydrates during severe HTP was also suggested to be responsible for the formation of droplets [32,33]. In this study, scanning electron microscopy (SEM) images demonstrated that the harsh HTP process $\left(210^{\circ} \mathrm{C}\right.$ for $0.5 \mathrm{~h}$ ) prompted migration or formation of lignins or pseudo-lignin (Figure 6A). Figure 6B shows a partial enlargement, revealing in more spherical droplets with different sizes. To sum up, SEM images suggested that the lignin or pseudo-lignin during the harsh HTP has inhomogeneous morphological features. To prove the fragmentation of lignins during the HTP, the molecular weights of the WSLs $\left(\mathrm{WSL}_{110(1.0)}, \mathrm{WSL}_{130(1.0)}, \mathrm{WSL}_{150(1.0)}\right.$, and $\mathrm{WSL}_{170(1.0)}$ ) were determined by GPC analysis (Table 4). It can be seen that an elevated HTP temperature caused the tremendous decrease of molecular weight in the WSLs, especially at higher temperature condition. Several researchers have investigated the evaluation of structural changes of lignins during the HTP process, and the results suggest that there

Table 3 Weight-average $\left(M_{\mathrm{w}}\right)$ and number-average $\left(M_{\mathrm{n}}\right)$ molecular weights and polydispersits $\left(M_{\mathrm{w}} / M_{\mathrm{n}}\right)$ of the water-soluble polysaccharides isolated from the hydrothermally pretreated liquor phase under the various processing conditions

\begin{tabular}{llllllllll}
\hline & \multicolumn{1}{l}{ Water-soluble polysaccharides (temperature $\left({ }^{\circ} \mathbf{C}\right)$-time $\left.(\mathbf{h})\right)$} \\
\cline { 2 - 10 } & $\mathbf{1 1 0 - 1 . 0}$ & $\mathbf{1 3 0 - 1 . 0}$ & $\mathbf{1 5 0 - 1 . 0}$ & $\mathbf{1 7 0 - 0 . 5}$ & $\mathbf{1 7 0 - 1 . 0}$ & $\mathbf{1 7 0 - 2 . 0}$ & $\mathbf{1 9 0 - 0 . 5}$ & $\mathbf{2 1 0 - 0 . 5}$ & $\mathbf{2 3 0 - 0 . 5}$ \\
\hline$M_{w}$ & 31,220 & 25,920 & 16,830 & 14,320 & 7,110 & 6,710 & 7,080 & 6,190 & 4,780 \\
$M_{n}$ & 15,550 & 14,160 & 8,520 & 7,670 & 6,240 & 5,930 & 6,150 & 5,620 & 4,020 \\
$M_{w} / M_{n}$ & 2.01 & 1.83 & 1.98 & 1.88 & 1.14 & 1.13 & 1.15 & 1.10 & 1.19 \\
\hline
\end{tabular}

Data represented are the averages of the results obtained from the duplicated experiments. 

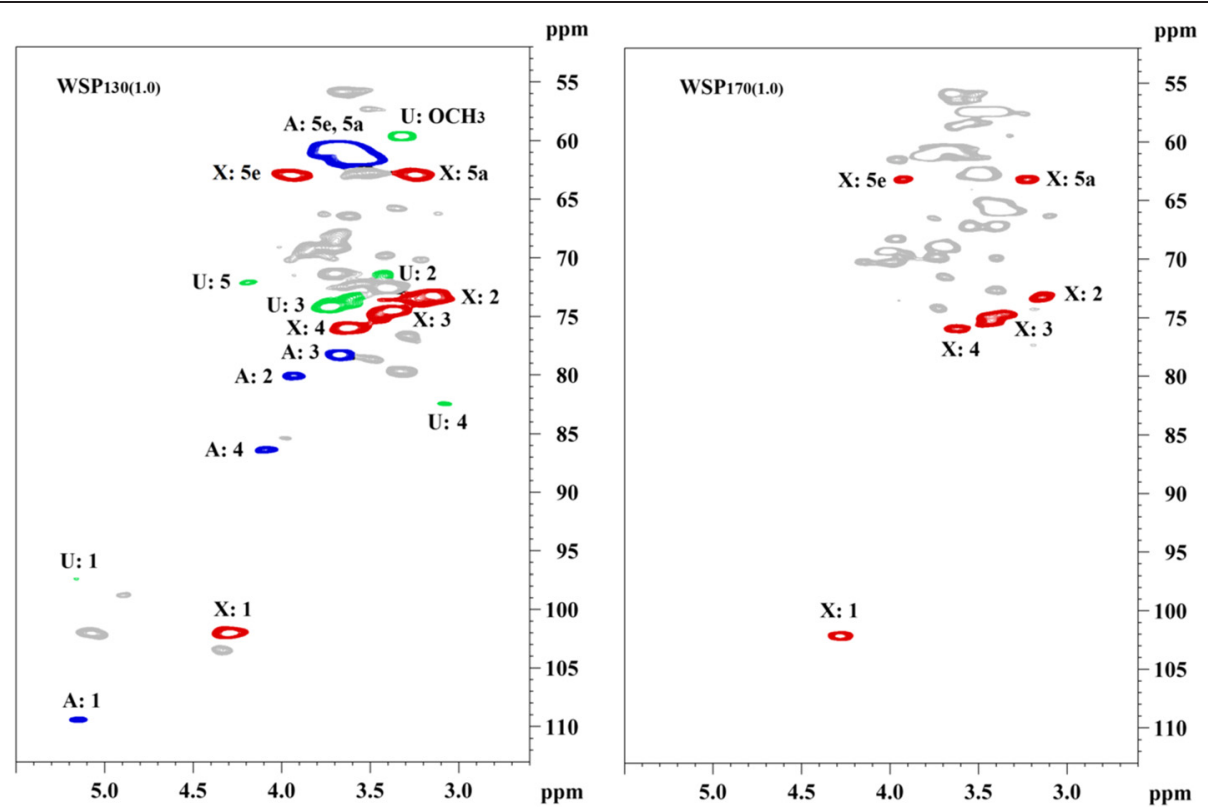

Figure $5 \mathrm{HSQC}$ spectra of water-soluble polysaccharides $\left(\mathrm{WSP}_{130(1.0)}\right.$ and $\left.\mathbf{W S P}_{170(1.0)}\right)$. HSQC, heteronuclear single quantum coherence; WSP, water-soluble polysaccharide; X, xylopyranosyl units; A, arabinofuranosyl units; U, 4-O-methyglucuronic acid.

is no significant decrease in the molecular weight of lignins. This was attributed to the partial protection of lignins by polysaccharides in the compact biomass matrix, which may facilitate the simultaneous re-condensation process occurring along with depolymerization [34]. Moreover, the polydispersity indices of the WSLs were slightly decreased (1.48 to 1.13 ) with an increasing pretreatment temperature from $110^{\circ} \mathrm{C}$ to $170^{\circ} \mathrm{C}$ for $1.0 \mathrm{~h}$, suggesting that more homogeneous lignin fragments were obtained under the harsh condition $\left(170^{\circ} \mathrm{C}\right.$ for $\left.1.0 \mathrm{~h}\right)$.

To further reveal structural differences of the WSLs $\left(\mathrm{WSL}_{130(1.0)}\right.$ and $\mathrm{WSL}_{170(1.0)}$ ) obtained from the liquor phase, the more detailed structural information was investigated by 2D-HSQC NMR spectra (Figure 7) [35-37]. The inter-unit linkages in the WSLs, $\beta$-ether $(\mathrm{A}, \beta-O-4)$ and phenylcoumaran $(\mathrm{C}, \beta-5)$ were identified due to the presence of cross-peaks at $\delta_{\mathrm{C}} / \delta_{\mathrm{H}} 71.5 / 4.82\left(\mathrm{~A}_{\alpha}\right), 60.2 / 3.60$ $\left(\mathrm{A}_{\gamma}\right)$, and 62.5/3.67 $\left(\mathrm{C}_{\gamma}\right)$, respectively. Moreover, the crosspeaks of methoxy groups in the WSLs $\left(-\mathrm{OCH}_{3}, \delta_{\mathrm{C}} / \delta_{\mathrm{H}}\right.$ $55.5 / 3.72)$ were clearly observed. The aromatic lignin units syringyl $(\mathrm{S})$, guaiacyl $(\mathrm{G})$ and $p$-hydroxyphenyl $(\mathrm{H})$ units showed prominent correlations at $\delta_{\mathrm{C}} / \delta_{\mathrm{H}} 103.6 / 6.63\left(\mathrm{~S}_{2,6}\right)$, $110.7 / 6.93\left(\mathrm{G}_{2}\right), 115.4 / 6.78\left(\mathrm{G}_{5}\right), 118.8 / 6.73\left(\mathrm{G}_{6}\right), 128.0 / 7.19$ $\left(\mathrm{H}_{2,6}\right)$, respectively. Minor amounts of oxidized $\mathrm{S}$ units $\left(\mathrm{S}^{\prime}\right)$ were detected due to the presence of a correlation at $\delta_{\mathrm{C}} / \delta_{\mathrm{H}}$ $106.8 / 7.20\left(\mathrm{~S}_{2,6}^{\prime}\right)$. In addition, the WSLs obtained appeared to contain small amounts of $p$-hydroxycinnamates ( $p$-coumaric and ferulic acids). The $p$-coumaric acid (PCA) was characterized by some relatively intense correlations at $\delta_{\mathrm{C}} / \delta_{\mathrm{H}} 129.8 / 7.49\left(\mathrm{PCA}_{2,6}\right), 115.0 / 6.27$ $\left(\mathrm{PCA}_{8}\right)$, and 144.0/7.47 $\left(\mathrm{PCA}_{7}\right)$, while ferulic acid (FA) was found at $\delta_{\mathrm{C}} / \delta_{\mathrm{H}} 110.9 / 7.31\left(\mathrm{FA}_{2}\right), 115.0 / 6.27\left(\mathrm{FA}_{8}\right)$, and $144.0 / 7.47\left(\mathrm{FA}_{7}\right)$. As can be seen, when the pretreatment temperature reached $170^{\circ} \mathrm{C}$, some expected changes appeared in the HSQC spectrum of $\mathrm{WSL}_{170(1.0)}$ as compared to that of $\mathrm{WSL}_{130(1.0) \text {. For example, the correlated }}$ signals $\left(\delta_{\mathrm{C}} / \delta_{\mathrm{H}} \quad 71.5 / 4.82,60.2 / 3.60,83.6 / 4.29\right.$, and $85.2 / 4.08)$ of $\beta-O-4$ were dramatically increased in WSL $_{170(1.0)}$. Meanwhile, the signal strength of polysaccharides reduced in $\mathrm{WSL}_{170(1.0)}$. This was mainly attributed to the degradation of polysaccharides, especially under the higher temperatures. The facts showed that more pure lignins were achieved under this condition. Besides, no signal of S' was detected in $\mathrm{WSL}_{170(1.0)}$, implying that the oxidized $S$ units occurred at a relatively lower temperature for a shorter time of pretreatment. The correlated signals of PCA were increased while the signals of FA were decreased as the pretreatment temperature increased from $110^{\circ} \mathrm{C}$ to $170^{\circ} \mathrm{C}$ for $1.0 \mathrm{~h}$.

\section{Process mass balance}

In this study, the maximum yield of XOS was achieved at $170^{\circ} \mathrm{C}$ for $0.5 \mathrm{~h}$ with a relatively low level of xylose and other by-products. Prolonged HTP time and higher temperature reduced the yield of XOS and enhanced the concentrations of monosaccharides and by-products. Therefore, a process mass balance of the HTP process was developed for the two HTP conditions $(0.5$ and $2.0 \mathrm{~h}$ at $170^{\circ} \mathrm{C}$ ) (Figure 8). Process yield was normalized to a common basis of $100 \mathrm{~kg}$ of dried SSS as the starting material [38]. It should be noted that, after the HTP, the liquor and solid were separated by filtration. The yields of the HTP 


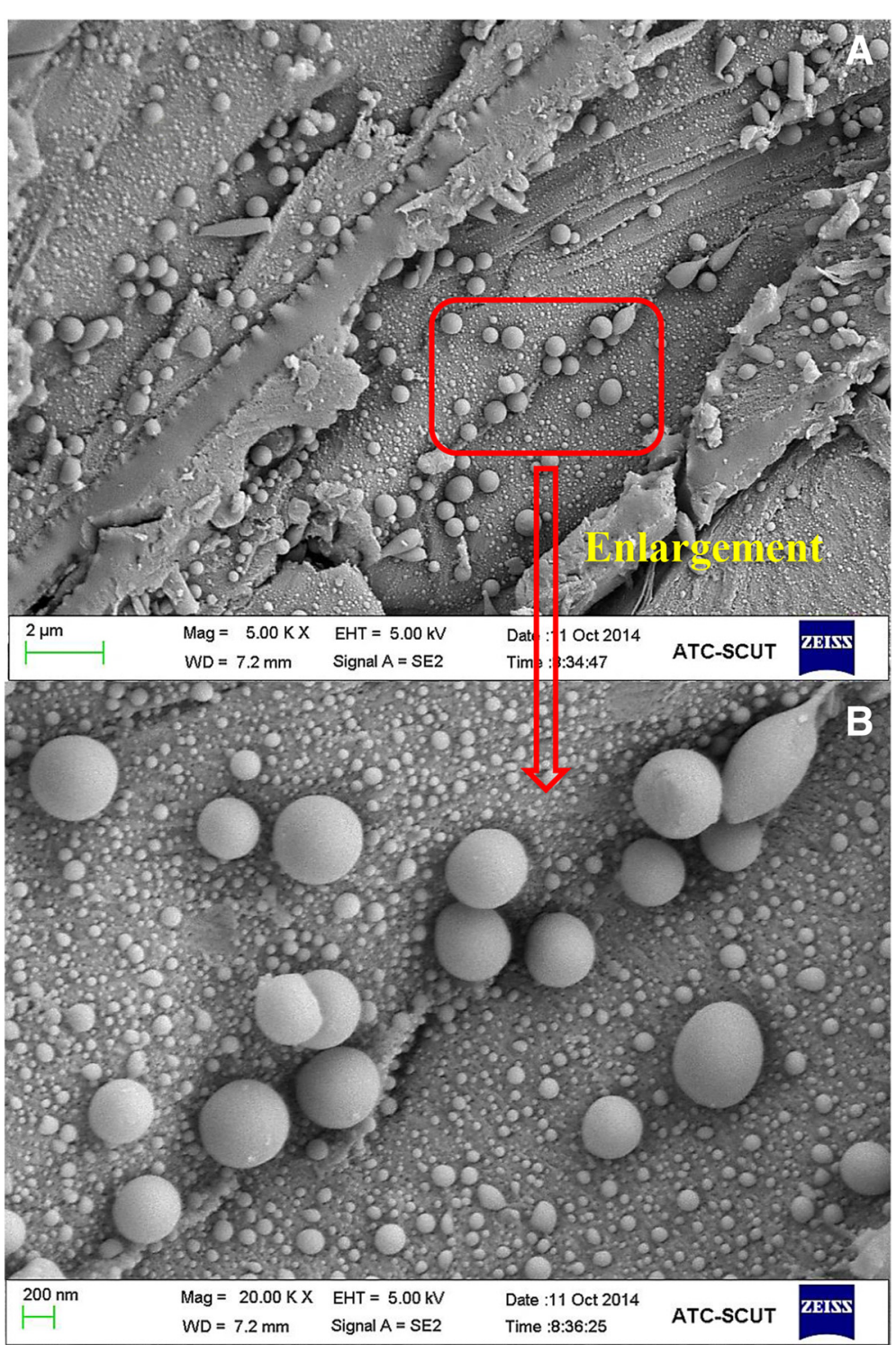

Figure 6 SEM images of the hydrothermally pretreated substrate at $210^{\circ} \mathbf{C}$ for $\mathbf{0 . 5} \mathbf{~ h}$. (A) Magnification $\times 5,000$. (B) Magnification $\times 20,000$. SEM, scanning electron microscopy.

residues decreased from 68.60 to $61.90 \mathrm{~kg}$ with an increasing HTP time from 0.5 to $2.0 \mathrm{~h}$ at $170^{\circ} \mathrm{C}$ [39]. It was found that 15.10 and $10.70 \mathrm{~kg}$ XOS could be obtained when the HTP processes were performed at $170^{\circ} \mathrm{C}$ for 0.5 and $2.0 \mathrm{~h}$, respectively (Figure 8 ). In addition, other more degraded products appeared in the liquor fractions for the prolonged HTP period, which was attributed to the significant degradation of hemicelluloses under the harsh HTP conditions.

\section{Conclusions}

The present study demonstrated that the hydrothermally pretreated conditions had significant influences on the compositions and their chemical structures of the degraded products. It was found that the maximum yield of XOS of $52.25 \%$ was achieved at $170^{\circ} \mathrm{C}$ for $0.5 \mathrm{~h}$ with a relatively low level of xylose and other degraded products. Higher temperature and/or longer reaction time reduced the yield of XOS and enhanced concentrations of monosaccharides (arabinose and galactose). In addition, as the pretreatment temperature and time increased, the concentrations of the degraded products (such as acetic acid and furfural) were dramatically increased. Furthermore, the 2D-HSQC spectrum of the XOS suggested that the XOS obtained mainly contained xylopyranosyl residues together with small amounts of 4-O-Me- $\alpha$-DGlcpA units. Molecular weights of the water-soluble polysaccharides and lignins implied that the degradation of the polysaccharides and lignins occurred at the harsh 
Table 4 Weight-average $\left(M_{\mathrm{w}}\right)$ and number-average $\left(M_{\mathrm{n}}\right)$ molecular weights and polydispersity indices $\left(M_{\mathrm{w}} / M_{\mathrm{n}}\right)$ of the water-soluble lignins isolated from the hydrothermally pretreated liquor phase under the various processing conditions

\begin{tabular}{lllll}
\hline & \multicolumn{4}{l}{ Water-soluble lignins (temperature $\left({ }^{\circ} \mathbf{C}\right)$-time $\left.(\mathbf{h})\right)$} \\
\cline { 2 - 5 } & $\mathbf{1 1 0 - 1 . 0}$ & $\mathbf{1 3 0 - 1 . 0}$ & $\mathbf{1 5 0 - 1 . 0}$ & $\mathbf{1 7 0 - 1 . 0}$ \\
\hline$M_{\mathrm{w}}$ & 1,610 & 1,590 & 1,050 & 950 \\
$M_{\mathrm{n}}$ & 1,090 & 1,220 & 900 & 840 \\
$M_{\mathrm{w}} M_{\mathrm{n}}$ & 1.48 & 1.30 & 1.17 & 1.13 \\
\hline
\end{tabular}

Data represented are the averages of the results obtained from the duplicated experiments.

conditions. Interestingly, 2D-HSQC spectra suggested that the water-soluble polysaccharides (rich in xylan) and water-soluble lignins (rich in $\beta-O-4$ linkages) were obtained at $170^{\circ} \mathrm{C}$ for $1.0 \mathrm{~h}$. In short, systematic evaluation of the degraded products during the hydrothermal pretreatment of SSS will be beneficial to value-added applications of multiple chemicals in a biorefinery process for bioethanol industry.

\section{Methods}

\section{Raw materials}

SSS was obtained from the experimental farm of the North-Western University of Agricultural and Forest Sciences and Technology (Yangling, Shaanxi, China). As determined by the National Renewable Energy Laboratory (NREL) using a two-step acid hydrolysis procedure, the extractive-free SSS was found to contain $41.1 \%$ glucan, $25.9 \%$ xylan, $2.3 \%$ arabinan, $0.7 \%$ galactan, and $21.4 \%$ lignin (19.5\% Klason lignin and 1.9\% acid-soluble lignin)
[40]. More details of the materials used in this study were given in a recent literature [26]. XOS (DP 2 to 6) standards were obtained from Megazyme (Megazyme International Ireland Ltd., Wicklow, Ireland). All chemicals were analytical grade and purchased from Sigma-Aldrich (Beijing, China).

\section{Hydrothermal pretreatment}

The HTP process was carried out in a 1,000-mL stainless steel autoclave (Parr Instrument Company, Moline, IL, USA) with a magnetic stirrer at a solid to liquor ratio of 1:10 $(\mathrm{g} / \mathrm{mL})$ by a PID controller (model 4848$)$. The HTP experiments were divided into nine batches, in each batch, $15.0 \mathrm{~g}$ the extractive-free material was mixed with $150 \mathrm{~mL}$ deionized water. Then, the mixture was heated at $110^{\circ} \mathrm{C}$, $130^{\circ} \mathrm{C}$, or $150^{\circ} \mathrm{C}$ for $1.0 \mathrm{~h}, 170^{\circ} \mathrm{C}$ for different periods $\left(0.5,1.0\right.$, or $2.0 \mathrm{~h}$ ), or $190^{\circ} \mathrm{C}, 210^{\circ} \mathrm{C}$, or $230^{\circ} \mathrm{C}$ for $0.5 \mathrm{~h}$. After the reaction, the reactor was cooled by cold water.

On the one hand, a liquor sample of $3 \mathrm{~mL}$ was posthydrolyzed with $4 \% \mathrm{H}_{2} \mathrm{SO}_{4}$ at $121^{\circ} \mathrm{C}$ for $1 \mathrm{~h}$ to determine the total concentration of XOS and their degree of substitution by acetyl group. The increased concentrations of monosaccharides and acetic acid after post-hydrolysis was regarded as the concentration of XOS and the amount of acetyl group attached on XOS, respectively $[41,42]$. According to this procedure, saccharides of DP 2 or higher were considered as XOS. This is different from the common definition of XOS which refers to a DP of 2 to 10. All the liquor samples were filtered through $0.22-\mu \mathrm{m}$ filter before analysis. The concentration of XOS was expressed as monosaccharides equivalents.

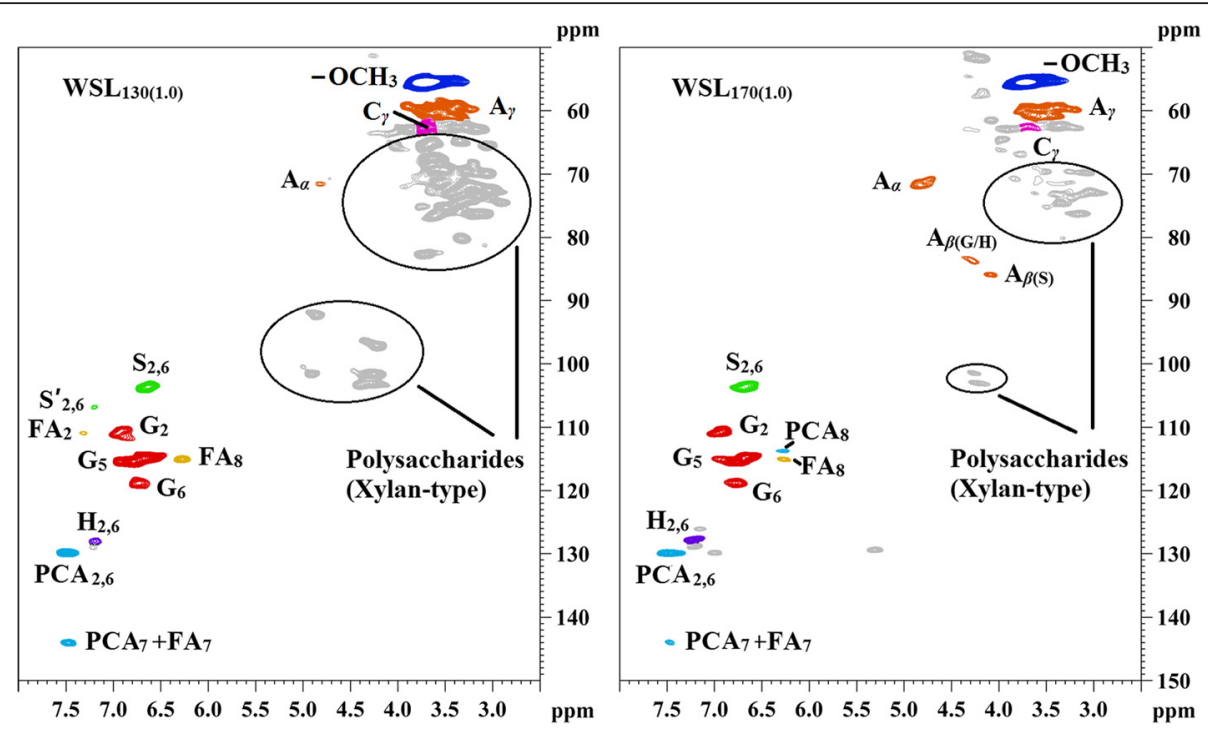

Figure $7 \mathrm{HSQC}$ spectra of water-soluble lignins $\left(\mathrm{WSL}_{130(1.0)}\right.$ and $\left.\mathrm{WSL}_{170(1.0)}\right)$. HSQC, heteronuclear single quantum coherence; WSL, watersoluble lignin; $A, \beta$-aryl-ether units $(\beta-O-4) ; C$, phenylcoumaran substructures $(\beta-5)$; PCA, free $p$-coumaric acid; FA, ferulate; $H, p$-hydroxyphenyl units; $G$, guaiacyl units; $S$, syringyl units; $S^{\prime}$, oxidized syringyl units bearing a carbonyl at $C_{a}$. 


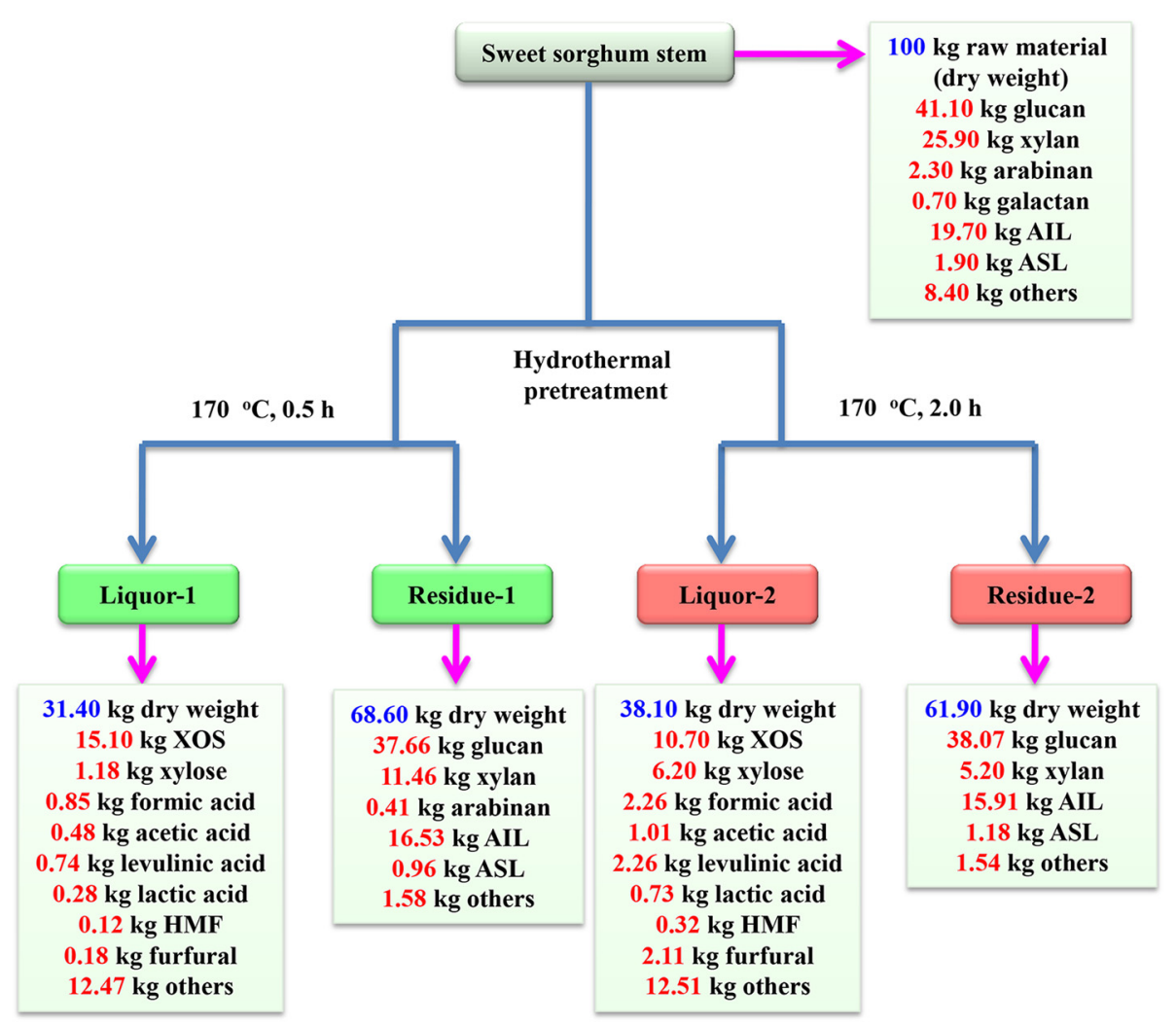

Figure 8 Mass balance during the pretreatment at $170^{\circ} \mathrm{C}$ for 0.5 and $2.0 \mathrm{~h}$.

On the other hand, the liquor $(100 \mathrm{~mL})$ was neutralized to $\mathrm{pH} 5.5$ to 6.0 with $6 \mathrm{M} \mathrm{NaOH}$ and were further concentrated to $40 \mathrm{~mL}$ under vacuum. Subsequently, each concentrated solution was poured into 95\% ethanol $(120 \mathrm{~mL})$ with vigorous stirring, and the WSP was obtained by filtering, washing with $70 \%$ aqueous ethanol. The supernatants were concentrated to $30 \mathrm{~mL}$ and poured in $150 \mathrm{~mL}$ acidic water $(\mathrm{pH}=2.0$, adjusted by $\mathrm{HCl})$ to precipitate the WSL. The detailed procedures are previously described in a publication [43]. The WSP and WSL obtained were freeze-dried using a lyophilizer (Thermo Modulyo Freeze Dryer; Thermo Scientific, Waltham, MA, USA) at $-50^{\circ} \mathrm{C}$ under vacuum for $48 \mathrm{~h}$.

\section{Analysis procedures}

HPAEC was used to quantify the monosaccharides and oligosaccharides of the liquor phase. An ICS-3000 HPAEC system with an AS50 autosampler, comprising a Carbopac PA-20 column $(4 \times 250 \mathrm{~mm}$, Dionex, Sunnyvale, CA, USA) for monosaccharides and a Carbopac PA-100 column $(4 \times 250 \mathrm{~mm}$, Dionex $)$ for oligosaccharides were used. The quantitative analysis of the degraded products (acetic acid, furfural, formic acid, levulinic acid, HMF, lactic acid) was determined on a high-performance liquid chromatography (HPLC, Agilent 1200 series, Agilent Technologies Inc., Santa Clara, CA, USA) using the method described in a previous paper with minor modification [44]. The XOS powder obtained in the case of the material pretreated at $170^{\circ} \mathrm{C}$ for $0.5 \mathrm{~h}$ was characterized by HSQC NMR. HSQC experiment was conducted with $20 \mathrm{mg}$ sample dissolved in $0.5 \mathrm{ml} \mathrm{D}_{2} \mathrm{O}$. The number of collected complex points was 1,024 for the ${ }^{1} \mathrm{H}$-dimension with a relaxation of $1.5 \mathrm{~s}$. The number of scans was 128 , and 256 time increments were recorded in ${ }^{13} \mathrm{C}$-dimension. The $1 J_{C-H}$ used was $146 \mathrm{~Hz}$. Prior to Fourier transformation, the data matrixes were zero filled up to 1,024 points in the ${ }^{13} \mathrm{C}$-dimension. Substrate (hydrothermally substrate pretreated at $210^{\circ} \mathrm{C}$ for $0.5 \mathrm{~h}$ ) was analyzed by SEM. SEM images were performed with a ZEISS EVO 18 (Carl Zeiss, Inc., Oberkochen, Germany). The accelerating voltage of the instrument was maintained at 5.00 and $20.00 \mathrm{kV}$.

The chemical compositions of the WSPs were analyzed by HPAEC. Each of the fractions $(5 \mathrm{mg})$ was hydrolyzed with $10 \% \mathrm{H}_{2} \mathrm{SO}_{4}$ at $105^{\circ} \mathrm{C}$ for $2.5 \mathrm{~h}$. Then, the hydrolysate was filtrated, diluted 50-fold, and injected into a HPAEC system (Dionex ICS 3000) with an amperometric detector, an AS50 autosample, a CarbopacTM PA-20 column $(4 \times 250 \mathrm{~mm}$, Dionex $)$, and a guard PA-20 column $(3 \times 30 \mathrm{~mm}$, Dionex). Neutral sugars and uronic acids were separated in a $5-\mathrm{mM} \mathrm{NaOH}$ isocratic (carbonate free and purged with nitrogen) for $20 \mathrm{~min}$, followed by a 0 to $75 \mathrm{mM} \mathrm{NaAc}$ gradient in a $5-\mathrm{mM} \mathrm{NaOH}$ for $15 \mathrm{~min}$. 
Then, the columns were washed with $200 \mathrm{mM} \mathrm{NaOH}$ for $10 \mathrm{~min}$ to remove the carbonate and followed by a 5 -min elution with $5 \mathrm{mM} \mathrm{NaOH}$ to re-equilibrate the column before the next injection [45]. The $M_{\mathrm{w}}$ and $M_{\mathrm{n}}$ molecular weights of all the WSPs were determined by GPC, using a PL aquagel-OH 50 column $(300 \times 7.7 \mathrm{~mm}$, Polymer Laboratories Ltd., Church Stretton, Shropshire, UK). The data were calibrated with PL pullulan polysaccharide standards. The detector used was a differential refractive index detector (RID). The eluent was $0.02 \mathrm{M} \mathrm{NaCl}$ in $0.005 \mathrm{M}$ sodium phosphate buffer ( $\mathrm{pH}$ 7.5), and the flow rate was $0.5 \mathrm{ml} / \mathrm{min}$. Soluble-state NMR spectra were conducted on a Bruker AVIII $400 \mathrm{MHz}$ spectrometer (Bruker AXS, Inc., Madison, WI, USA). HSQC NMR technique has also been applied to the structural determination of the WSPs based on the aforementioned conditions (XOS). The $M_{\mathrm{w}}$ and $M_{\mathrm{n}}$ of the WSLs were determined by GPC with an ultraviolet detector (UV) at $240 \mathrm{~nm}$. The column used was a PL gel $10 \mathrm{~mm}$ mixed-B $7.5 \mathrm{~mm}$ i.d. column, which was calibrated with PL polystyrene standards. For 2D-HSQC spectra, the Bruker pulse program "hsqcetgpsi" was used and the parameters used is listed as below: the number of collected complex points was $1 \mathrm{~K}$ for the ${ }^{1} \mathrm{H}$ dimension with $\mathrm{d}_{1}(2 \mathrm{~s})$, number of scanning is 64 , and 256 time increments were always recorded.

\section{Abbreviations \\ 2D-HSQC: two-dimensional heteronuclear single quantum coherence; DP: degree of polymerization; FA: ferulic acid; G: guaiacyl; GPC: gel permeation chromatography; H: p-hydroxyphenyl; HMF: hydroxymethylfurfural; HPAEC: high-performance anion exchange chromatography; HPLC: high-performance liquid chromatography; HTP: hydrothermal pretreatment; $M_{n}$ : number-average; $M_{w}$ : weight-average; NREL: National Renewable Energy Laboratory's; PCA: free $p$-coumaric acid; PDI: polydispersity indexes; RID: refractive index detector; S: syringyl; SEM: scanning electron microscopy; SSS: sweet sorghum stem; WSL: water-soluble lignins; WSP: water-soluble polysaccharide; XOS: xylo-oligosaccharides.}

\section{Competing interests}

The authors declare that they have no competing interests.

\section{Authors' contributions}

SLS completed performed the major experiments, analyzed the data, and prepared the manuscript. JLW and SNS helped with the overall pretreatment experiments of the pretreatment and the instrumental analysis. RCS designed the project, supervised the experiments, and finalized the manuscript. All authors read and approved the final manuscript.

\section{Acknowledgements}

The authors are extremely grateful for the financial support from the National Science Foundation of China (31430092) and the State Forestry Administration (20124803).

Received: 16 November 2014 Accepted: 4 February 2015

Published online: 04 March 2015

\section{References}

1. Fargione J, Hill J, Tilman D, Polasky S, Hawthorne P. Land clearing and the biofuel carbon debt. Science. 2012;319:1235-8.

2. Himmel ME, Ding SY, Johnson DK, Adney WS, Nimlos MR, Brady JW, et al. Biomass recalcitrance: engineering plants and enzymes for biofuels production. Science. 2007;315:804-7.
3. Prakasham RS, Nagaiah D, Vinutha KS, Uma A, Chiranjeevi T, Umakanth AV, et al. Sorghum biomass: a novel renewable carbon source for industrial bioproducts. Biofuels. 2012;5:159-74.

4. Massacci A, Battistelli A, Loreto F. Effect of drought stress on photosynthetic characteristics, growth and sugar accumulation of field-grown sweet sorghum. Funct Plant Biol. 1996;23:331-40.

5. Alvira P, Tomás-Pejó E, Ballesteros M, Negro M. Pretreatment technologies for an efficient bioethanol production process based on enzymatic hydrolysis: a review. Bioresour Technol. 2010;10:4851-61.

6. Sun $S N$, Cao XF, Sun SL, Xu F, Song XL, Jones GL. Improving the enzymatic hydrolysis of thermo-mechanical fiber from Eucalyptus urophylla by a combination of hydrothermal pretreatment and alkali fractionation. Biotechnol Biofuels. 2014;7:116.

7. Moreno AD, Tomás-Pejó E, Ibarra D, Ballesteros M, Olsson L. Fed-batch SSCF using steam-exploded wheat straw at high dry matter consistencies and a xylose-fermenting Saccharomyces cerevisiae strain: effect of laccase supplementation. Biotechnol Biofuels. 2013;6:160.

8. Park N, Kim HY, Koo BW, Yeo H, Choi IG. Organosolv pretreatment with various catalysts for enhancing enzymatic hydrolysis of pitch pine (Pinus rigida). Bioresour Technol. 2010;101:7046-53.

9. Zhang T, Wyman CE, Jakob K, Yang B. Rapid selection and identification of Miscanthus genotypes with enhanced glucan and xylan yields from hydrothermal pretreatment followed by enzymatic hydrolysis. Biotechnol Biofuels. 2012;5:56.

10. Pu YQ, Hu F, Huang F, Davison BH, Ragauskas AJ. Assessing the molecular structure basis for biomass recalcitrance during dilute acid and hydrothermal pretreatments. Biotechnol Biofuels. 2013;6:15.

11. Romaní A, Garrote G, Alonso JL, Parajó JC. Bioethanol production from hydrothermally pretreated Eucalyptus globulus wood. Bioresour Technol. 2010;101:8706-12.

12. Liu S. Woody biomass: niche position as a source of sustainable renewable chemicals and energy and kinetics of hot-water extraction/hydrolysis. Biotechnol Adv. 2010;28:563-82.

13. Sun SL, Sun SN, Wen JL, Zhang XM, Peng F, Sun RC. Assessment of integrated process based on hydrothermal and alkaline treatments for enzymatic saccharification of sweet sorghum stems. Bioresour Technol. 2014;175:473-9.

14. Garrote G, Kabel MA, Schols HA, Falqué E, Domínguez H, Parajó JC. Effects of Eucalyptus globulus wood autohydrolysis conditions on the reaction products. J Agric Food Chem. 2007;55:9006-13.

15. Kabel MA, Bos G, Zeevalking J, Voragen AG, Schols HA. Effect of pretreatment severity on xylan solubility and enzymatic breakdown of the remaining cellulose from wheat straw. Bioresour Technol. 2007;98:2034-42.

16. Marzialetti T, Valenzuela Olarte MB, Sievers C, Hoskins TJ, Agrawal PK, Jones CW. Dilute acid hydrolysis of Loblolly pine: a comprehensive approach. Ind Eng Chem Res. 2008:47:7131-40.

17. Xiao X, Bian J, Peng XP, Xu H, Xiao B, Sun RC. Autohydrolysis of bamboo (Dendrocalamus giganteus Munro) culm for the production of xylo-oligosaccharides. Bioresour Technol. 2013;138:63-70.

18. Nitsos CK, Matis KA, Triantafyllidis KS. Optimization of hydrothermal pretreatment of lignocellulosic biomass in the bioethanol production process. ChemSusChem. 2013;6:110-22.

19. Moure A, Gullón P, Domínguez H, Parajó JC. Advances in the manufacture, purification and applications of xylo-oligosaccharides as food additives and nutraceuticals. Process Biochem. 2006;41:1913-23.

20. Akpinar O, Erdogan K, Bakir U, Yilmaz L. Comparison of acid and enzymatic hydrolysis of tobacco stalk xylan for preparation of xylooligosaccharides. LWT-Food Sci Technol. 2010;43:119-25.

21. Bian J, Peng F, Peng XP, Peng P, Xu F, Sun RC. Structural features and antioxidant activity of xylooligosaccharides enzymatically produced from sugarcane bagasse. Bioresour Technol. 2013;127:236-41.

22. Dunlop A. Furfural formation and behavior. Ind Eng Chem. 1948;40:204-9.

23. Horvat J, Klaić B, Metelko B, Šunjić V. Mechanism of levulinic acid formation. Tetrahedron Lett. 1985:26:2111-4.

24. Palmqvist E, Hahn-Hägerdal B. Fermentation of lignocellulosic hydrolysates. II: inhibitors and mechanisms of inhibition. Bioresour Technol. 2000; $74: 25-33$

25. Peng P, Peng F, Bian J, Xu F, Sun R. Studies on the starch and hemicelluloses fractionated by graded ethanol precipitation from bamboo Phyllostachys bambusoides f. shouzhu Yi. J Agric Food Chem. 2011;59:2680-8. 
26. Sun $\mathrm{SL}$, Wen $J$, Ma MG, Song XL, Sun RC. Integrated biorefinery based on hydrothermal and alkaline treatments: investigation of sorghum hemicelluloses. Carbohyd Polym. 2014;111:663-9.

27. Siqueira G, Milagres AMF, Carvalho W, Koch G, Ferraz A. Topochemical distribution of lignin and hydroxycinnamic acids in sugar-cane cell walls and its correlation with the enzymatic hydrolysis of polysaccharides. Biotechnol Biofuels. 2011;4:7.

28. Rezende CA, de Lima MA, Maziero P, DeAzevedo ER, Garcia W, Polikarpov I. Chemical and morphological characterization of sugarcane bagasse submitted to a delignification process for enhanced enzymatic digestibility. Biotechnol Biofuels. 2011;4:54

29. El Hage R, Chrusciel L, Desharnais L, Brosse N. Effect of autohydrolysis of Miscanthus $x$ giganteus on lignin structure and organosolv delignification. Bioresour Technol. 2010;101:9321-9.

30. Selig MJ, Viamajala S, Decker SR, Tucker MP, Himmel ME, Vinzant TB. Deposition of lignin droplets produced during dilute acid pretreatment of maize stems retards enzymatic hydrolysis of cellulose. Biotechnol Progr. 2007;23:1333-9.

31. Donohoe BS, Decker SR, Tucker MP, Himmel ME, Vinzant TB. Visualizing lignin coalescence and migration through maize cell walls following thermochemical pretreatment. Biotechnol Bioeng. 2008;101:913-25.

32. Sannigrahi $P$, Ragauskas AJ, Miller SJ. Effects of two-stage dilute acid pretreatment on the structure and composition of lignin and cellulose in loblolly pine. BioEnerg Res. 2008;1:205-14.

33. Kumar R, Hu F, Sannigrahi P, Jung S, Ragauskas AJ, Wyman CE. Carbohydrate derived-pseudo-lignin can retard cellulose biological conversion. Biotechnol Bioeng. 2013;110:737-53.

34. Samuel R, Cao S, Das BK, Hu F, Pu Y, Ragauskas AJ. Investigation of the fate of poplar lignin during autohydrolysis pretreatment to understand the biomass recalcitrance. RSC Adv. 2013;3:5305-9.

35. del Río JC, Rencoret J, Marques G, Li J, Gellerstedt G, Jiménez-Barbero J, et al. Structural characterization of the lignin from jute (Corchorus capsularis) fibers. J Agric Food Chem. 2009;57:10271-81.

36. Wen $J$, Xue BL, Xu F, Sun RC, Pinkert A. Unmasking the structural features and property of lignin from bamboo. Ind Crop Prod. 2013;42:332-43.

37. Ralph J, Lundquist K, Brunow G, Lu F, Kim H, Schatz PF, et al. Lignins: natural polymers from oxidative coupling of 4-hydroxyphenyl-propanoids. Phytochem Rev. 2004;3:29-60.

38. Percival Zhang YH, Berson E, Sarkanen S, Dale BE. Sessions 3 and 8: pretreatment and biomass recalcitrance: fundamentals and progress. Appl Biochem Biotech. 2009;153:80-3.

39. Sun SL, Wen JL, Ma MG, Sun RC. Structural elucidation of sorghum lignins from integrated biorefinery process based on hydrothermal and alkaline treatments. J Agric Food Chem. 2014;62:8120-8.

40. Sluiter A, Hames B, Ruiz R, Scarlata C, Sluiter J, Templeton D, et al. Determination of structural carbohydrates and lignin in biomass. Golden CO: National Renewable Energy Laboratory; 2008. Technical Report NREL/TP-510-42618.

41. Gullón B, Yáñez R, Alonso J, Parajó J. Production of oligosaccharides and sugars from rye straw: a kinetic approach. Bioresour Technol. 2010;101:6676-84

42. Nabarlatz D, Farriol X, Montané D. Kinetic modeling of the autohydrolysis of lignocellulosic biomass for the production of hemicellulose-derived oligosaccharides. Ind Eng Chem Res. 2004;43:4124-31.

43. Sun RC, Lawther JM, Banks WB. Effects of extraction time and different alkalis on the composition of alkali-soluble wheat straw lignins. J Agric Food Chem. 1996:44:3965-70.

44. Yang HY, Wang $\mathrm{K}, \mathrm{Xu}$ F, Sun RC, Lu YB. $\mathrm{H}_{2} \mathrm{SO}_{4}$-catalyzed hydrothermal pretreatment of triploid poplar to enhance enzymatic hydrolysis. Ind Eng Chem Res. 2012;51:11598-604.

45. Bian J, Peng F, Peng P, Xu F, Sun RC. Isolation and fractionation of hemicelluloses by graded ethanol precipitation from Caragana korshinskii. Carbohyd Res. 2010;345:802-9.

\section{Submit your next manuscript to BioMed Central and take full advantage of:}

- Convenient online submission

- Thorough peer review

- No space constraints or color figure charges

- Immediate publication on acceptance

- Inclusion in PubMed, CAS, Scopus and Google Scholar

- Research which is freely available for redistribution

Submit your manuscript at www.biomedcentral.com/submit 